\title{
Effect of indigo dye effluent on the growth, biomass production and phenotypic plasticity of Scenedesmus quadricauda (Chlorococcales)
}

\author{
MATHIAS A. CHIA ${ }^{1}$ and RILWAN I. MUSA ${ }^{2}$ \\ ${ }^{1}$ Laboratório de Cianobactérias, Escola Superior de Agricultura Luiz de Queiroz, \\ Universidade de São Paulo, Av. Pádua Dias, 11, 13418-900 Piracicaba, SP, Brasil \\ ${ }^{2}$ Department of Biological Sciences, Ahmadu Bello University, Zaria, Postal Code 810001 , Nigeria
}

Manuscript received on June 26, 2013; accepted for publication on October 14, 2013

\begin{abstract}
The effect of indigo dye effluent on the freshwater microalga Scenedesmus quadricauda ABU12 was investigated under controlled laboratory conditions. The microalga was exposed to different concentrations of the effluent obtained by diluting the dye effluent from 100 to 175 times in bold basal medium (BBM). The growth rate of the microalga decreased as indigo dye effluent concentration increased $(p<0.05)$. The $\mathrm{EC}_{50}$ was found to be 166 dilution factor of the effluent. Chlorophyll $a$, cell density and dry weight production as biomarkers were negatively affected by high indigo dye effluent concentration, their levels were higher at low effluent concentrations $(p<0.05)$. Changes in coenobia size significantly correlated with the dye effluent concentration. A shift from large to small coenobia with increasing indigo dye effluent concentration was obtained. We conclude that even at low concentrations; effluents from textile industrial processes that use indigo dye are capable of significantly reducing the growth and biomass production, in addition to altering the morphological characteristics of the freshwater microalga S. quadricauda. The systematic reduction in the number of cells per coenobium observed in this study further confirms that environmental stress affects coenobium structure in the genus Scenedesmus, which means it can be considered an important biomarker for toxicity testing.
\end{abstract}

Key words: freshwater, microalgae, morphological variation, pollution, textile waste.

\section{INTRODUCTION}

Textile industrial processes consume large amounts of water and use toxic products. They contribute to the degradation of the environment by releasing untreated dye effluents into neighboring aquatic ecosystems in the form of sludge. The final disposal of this sludge remains a challenge, and its ecotoxicological assessment is important for minimizing its environmental impacts. Even when

Correspondence to: Mathias Ahii Chia

E-mail: chia28us@yahoo.com treated, conventional waste treatment techniques do not completely decolorize and detoxify the dye effluents (Puvaneswari et al. 2006).

Indigo dye is part of the numerous marketed organic colorants used for coloration of textiles, paper, leather, plastic and for specialized applications such as food, drug, cosmetic and photochemical productions (Zollinger 1987, Novotny et al. 2006). Textile effluents containing indigo dye and other dye types make water toxic (Robinson et al. 2001) and unfit for human and 
animal consumption, and cause imbalance within different aquatic ecosystem food chains (Rocha 1992). In recent years various researchers have identified mutagenic effects of textile samples and waste water of the textile industry (Knasmüller et al. 1993, Jäger 1998, Mathur et al. 2012). Their findings show that dyes used for textile finishing are mainly responsible for the mutagenic effects observed. Although information on textile dye toxicity to microalgae remain scanty, Rannug et al. (1992), Mathur et al. (2005a, b), and Mathur and Bhatnagar (2007) were able to show that indigo dye had mutagenic effect on the bacterium Salmonella typhimurium.

The effluents of textile dyeing and printing industries are complex in nature, rich in dissolved and suspended solids, organic compounds, heavy metals and have high $\mathrm{pH}$. The composition of textile effluents determines the extent to which they pollute rivers (Srivastava et al. 1994), affect soil characteristics (Raj et al. 1997), and affect plants (Khandelwal 1996, Raj et al. 1997). Hence, we hypothesize that the complex nature of indigo dye effluent would be responsible for the overall toxicity observed and not just the dye component alone. This is because the presence of metals like cadmium, chromium and copper in textile effluents can exhibit various interactive toxic effects on aquatic biota (Mathur et al. 2012). The final toxic effect of the indigo dye effluent may be synergistic, additive or antagonistic as a function of the different effluent components that make up the effluent and not the dye in isolation.

Scenedesmus chosen for this study is cosmopolitan and can be found in a wide array of aquatic ecosystems ranging from oligo-, meso-, eutrophic and metal polluted waters. Scenedesmus quadricauda forms miniature colonies termed autocolonies or coenobia, in which groups of 4 to 8 cells are connected together in a row. The morphological form i.e. the number of cells per coenobium of Scenedesmus varies depending on environmental conditions and the physiological state. Under environmental stress, it may fail to produce such colonies (van Den Hoek et al. 1995, Lurling and van Donk 1999, Lombardi et al. 2007). These changes in phenotypic plasticity are considered a response to environmental stress (Lurling and Beekman 2002, Peña-Castro et al. 2004).

To the best of our knowledge, nothing is known about the effect of indigo dye effluents on freshwater microalgae. Due to the extent to which the dye is extensively used today in the textile and allied industries, understanding the effects of the indigo dye effluents is very important and requires investigations. Detection and quantification of the morphological response is easy and inexpensive, and thus very relevant in environmental monitoring (Lombardi et al. 2007). This study was aimed at determining the effect of indigo dye effluent on the growth, biomass production and phenotypic plasticity of $S$. quadricauda.

\section{MATERIALS AND METHODS}

The Scenedesmus quadricauda ABU12 strain used in this study was isolated from a freshwater pond in Zaria, Nigeria. It was maintained in the laboratory with Bold Basal Medium (BBM) at $23 \pm 2^{\circ} \mathrm{C}$ and under continuous illumination at $150 u \mathrm{ml}$ photons $\mathrm{m}^{-2} \mathrm{~s}^{-1}$ using cool white fluorescent lamps. Culture media sterilization was performed through autoclaving at $121^{\circ} \mathrm{C}$ for $15 \mathrm{~min}$, and the media were left to stand and equilibrate for $24 \mathrm{~h}$ before use. Sterile techniques were maintained throughout the experimental period.

Dye effluent samples were collected from local textile industries located in Zaria, Nigeria. In order to confirm the identity of the dye used in the local dye industries, we purchased raw indigo dye from Emmybiz Dye and Chemicals International Limited, Sabon Gari, Zaria, Nigeria. This dye company supplies the local textile industries in Zaria with indigo dye. The identification of the raw dye and the dye in the effluent were done using spectroscopic methods by observing its absorption at different 
wavelengths with the aid of a SpectrumLab 7525 UV-VIS spectrophotometer (B. Bran Scientific and Instrument Company, England). In addition, Fourier Transform Infrared Analysis (FTIR) was used to determine the different functional groups of the dye as a way of confirming its identification. About $1 \mathrm{mg}$ was weighed in a small agate mortar with a drop of nujol and Kbr. The mull was then pressed between the flat plates of sodium chloride. Before running a scan on each sample type, a background scan was carried out. All scanning was done from 4000 to $625 \mathrm{~cm}^{-1}$ (Williams and Fleming 2005) using a Shimadzu FT-IR Model 8400s spectrophotometer (Shimadzu, Japan).

The effluent was characterized for physical and chemical properties. $\mathrm{pH}$ and electrical conductivity levels were determined using HANNA pH/ EC/Temp meter model 210, and turbidity was determined spectrophotometrically. Biochemical oxygen demand, dissolved oxygen and chemical oxygen demand were determined using the Azide Modification of the Winkler method as described in APHA (1998). Nitrate nitrogen, phosphate phosphorus and total sulphate were determined using the spectrophotometric procedures described in APHA (1998). Cadmium, chromium and copper concentrations were determined using flame atomic absorption spectroscopy (FAAS) (Shimadzu Model AA6800, Shimadzu, Japan). The physicochemical characteristics of the indigo dye effluent are presented in Table I.

Preliminary screening was done with the microalga for its ability to grow in the dye effluent. Exponential growing cultures were inoculated into different effluent concentrations (10 to $100 \%$ ) in BBM in $200 \mathrm{~mL}$ using Erlenmeyer flasks. The cultures were grown for 7 days under controlled laboratory conditions listed above. Prior to inoculation, $\mathrm{pH}$ was adjusted to $7 \pm 0.3$. This preliminary test showed no visible growth was observed under these conditions. Therefore, further dilutions of the original effluent were
TABLE I

The physicochemical characteristics of the Indigo dye effluents used in the present study.

\begin{tabular}{lc}
\hline Physicochemical parameters & Value \\
\hline Nitrate nitrogen $\left(\mathrm{mg} \mathrm{L}^{-1}\right)$ & 0.001 \\
Phosphate phosphorous $\left(\mathrm{mg} \mathrm{L}^{-1}\right)$ & 50.500 \\
Dissolved oxygen $\left(\mathrm{mg} \mathrm{L}^{-1}\right)$ & 19.400 \\
Chemical oxygen demand $\left(\mathrm{mg} \mathrm{L}^{-1}\right)$ & 24.000 \\
Electrical conductivity & 19.710 \\
Temperature $\left({ }^{\circ} \mathrm{C}\right)$ & 28.200 \\
$\mathrm{pH}$ & 6.700 \\
$\mathrm{Biological}$ oxygen demand $\left(\mathrm{mg} \mathrm{L}^{-1}\right)$ & 0.000 \\
$\mathrm{Cu}\left(\mathrm{mg} \mathrm{L}^{-1}\right)$ & 0.054 \\
$\mathrm{Cr}\left(\mathrm{mg} \mathrm{L}^{-1}\right)$ & 0.183 \\
$\mathrm{Cd}\left(\mathrm{mg} \mathrm{L}^{-1}\right)$ & 0.003 \\
\hline
\end{tabular}

made to a factor range of 100 to 175 times. The control treatment with no dye effluent addition was represented as normal BBM. The microalga was acclimated to the BBM using semi-continuous batch system. When the microalga was at mid exponential growth phase, dilutions were made by re-inoculating at a $10 \% \mathrm{v} / \mathrm{v}$ until a steady state physiological growth status was obtained. This is the stage where the growth rate was statistically the same and reflecting the growth condition to which S. quadricauda was exposed. It is this exponential phase growing $S$. quadricauda that was exposed to the different dye dilution treatments to give an initial cell density of $10^{4}$ cells $\mathrm{mL}^{-1}$ and monitored for a period of 4 days (0-96 h). All experiments were carried out in triplicates.

The growth of the cultures was monitored by taking aliquots from the cultures on a daily basis for absorbance and cell density measurements. Specific growth was determined using the natural logarithmic transformed regression growth curve. Cell counts were determined by using direct microscopic counts with a Naubauer Brightline Haemocytometer. Dry weight was determined gravimetrically by using pre-weighed Sartorius $0.22 u \mathrm{M}$ pore size membrane filters. The extraction and analysis of chlorophyll $a$ was carried out in line with the procedures of Shoaf and Lium 
(1976). Pigment quantification was done using the equations provided by Németh (1998). Number of cells per coenobium was determined under the microscope to see if there was any relationship between the level of the effluent and the number of cells per coenobium.

The data obtained from this study was subjected to Levene's homogeneity variance test. A two-way ANOVA was used to test for significant differences between response parameters (growth, biomass production and phenotypic plasticity) of the microalga under the different indigo dye effluent concentrations. Tukey's HSD post hoc test was used to separate the significantly different means from the ANOVA computations. The relationship between the different parameters measured and the treatment conditions was determined using a correlations based principal components analysis (PCA). Homogeneity, ANOVA and Tukey's HSD tests were performed using Statistica for windows, while PCA was obtained using PAST statistical software. Effective concentration $50\left(\mathrm{EC}_{50}\right)$ was determined using the EPA Probit Analysis program version 1.5 for windows. All analyses were done at $5 \%$ significance level.

\section{RESULTS}

This research focused on the effect of indigo dye effluents on the growth, biomass production and morphological plasticity (number of cells per coenobium) of $S$. quadricauda. The growth rate of the microalga was highest in the control but decreased with increasing effluent concentration i.e. decreasing dilution rate (Table II). Furthermore, the $\mathrm{EC}_{50}$ concentration was 165 dilution of the original dye effluent. The control supported the highest chlorophyll $a$ production and cell density among all treatments (Figs.1 and 2). Fig. 3 shows that dry weight production in the control increased over time, while the response in the different treatment was somewhat different. The lowest dye concentration had similar dry weight production to that observed in the control, while at higher dye concentrations variable biomass production was observed over the study period. Differences in cell density, dry weight and pigment concentration over time with increasing concentration of the dye treatments were obtained (ANOVA, $p<0.05$; Table III).

TABLE II

Specific growth rate $\left(\mathrm{d}^{-1}\right)$ and $\mathrm{EC}_{50}$ value of Scenedesmus quadricauda grown at different effluent concentrations.

\begin{tabular}{cc}
\hline Treatment & Specific growth rate $\left(\mathbf{d}^{-\mathbf{1}}\right)$ \\
\hline Control & 0.93 \\
175 & 0.87 \\
150 & 0.47 \\
125 & 0.40 \\
100 & 0.05 \\
\hline $\mathrm{EC}_{50}$ & 165.52 \\
\hline
\end{tabular}

TABLE III

ANOVA summary results for the various parameters of Scenedesmus quadricauda analyzed after exposure to different dye effluent concentrations. N.B: where $P$ value is less than 0.05, the ANOVA F value is significant.

\begin{tabular}{lcccccc}
\hline \multicolumn{1}{c}{ Parameters } & $\begin{array}{c}\text { Treatment } \\
\text { F value }\end{array}$ & $\begin{array}{c}\text { Treatment } \\
\text { P value }\end{array}$ & $\begin{array}{c}\text { Time } \\
\text { F value }\end{array}$ & $\begin{array}{c}\text { Time } \\
\text { P value }\end{array}$ & $\begin{array}{c}\text { Treatment vs. } \\
\text { Time F Value }\end{array}$ & $\begin{array}{c}\text { Treatment vs. } \\
\text { Time P value }\end{array}$ \\
\hline Cell count & 7.1833 & 0.000186 & 24.1 & 0 & 2.153 & 0.035 \\
Dry weight & 2.743 & 0.0417 & 13.953 & 0 & 2.432 & 0.0176 \\
Chlorophyll a & 1.371 & 0.261 & 1.203 & 0.32 & 1.313 & 0.249 \\
1 cell per coenobium & 38.188 & 0 & 4.283 & 0.0103 & 1.0436 & 0.431 \\
2 cell per coenobium & 2.025 & 0.109 & 3.531 & 0.023 & 1.512 & 0.16 \\
3 cell per coenobium & 3.924 & 0.008 & 1.026 & 0.391 & 1.146 & 0.353 \\
4 cell per coenobium & 41.158 & 0 & 1.61 & 0.202 & 0.69 & 0.753 \\
\hline
\end{tabular}




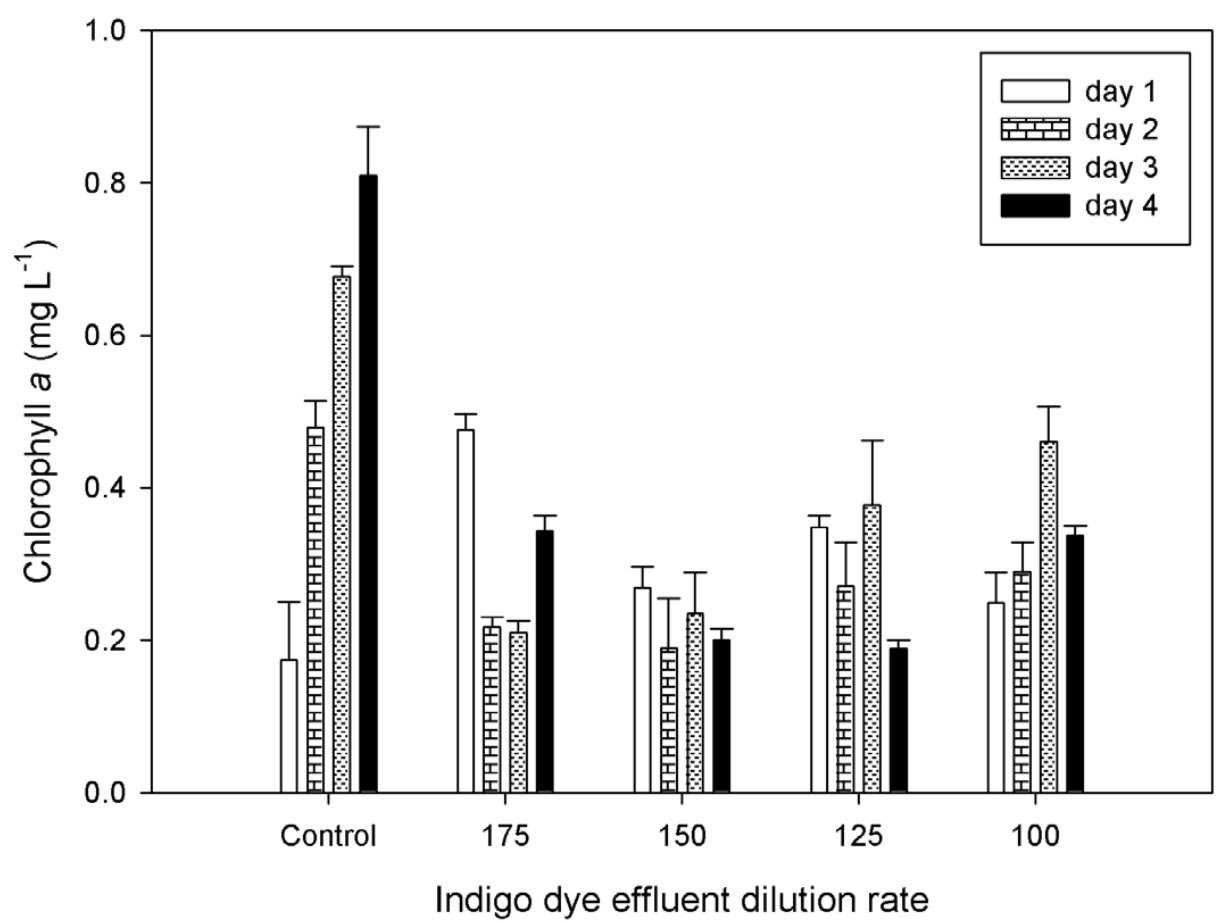

Fig. 1 - Chlorophyll a concentration $\left(\mathrm{mg} \mathrm{L}^{-1}\right)$ of Scenedesmus quadricauda exposed to different indigo dye effluent concentrations.

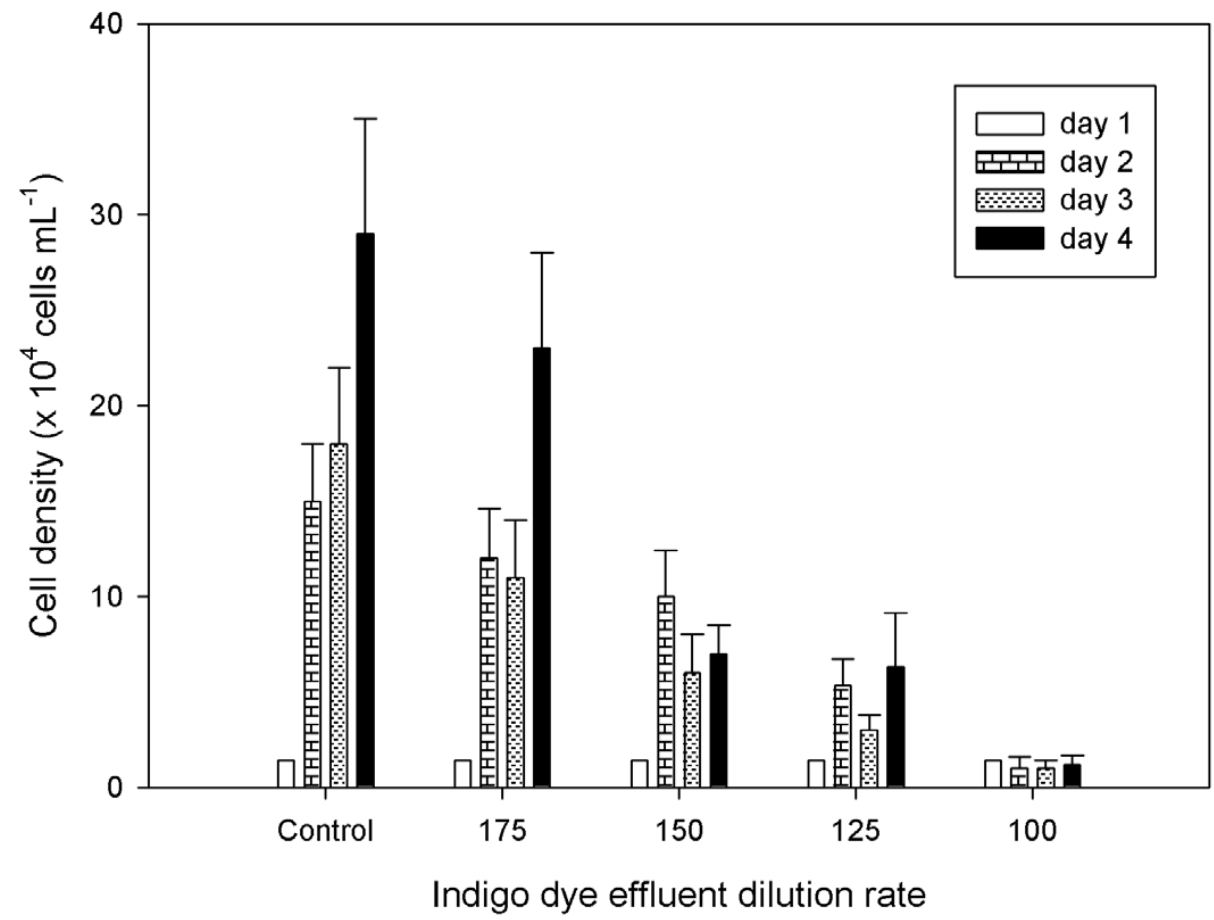

Fig. 2 - Cell density (cells $\mathrm{mL}^{-1}$ ) of Scenedesmus quadricauda as a function of different indigo dye effluent concentrations. 


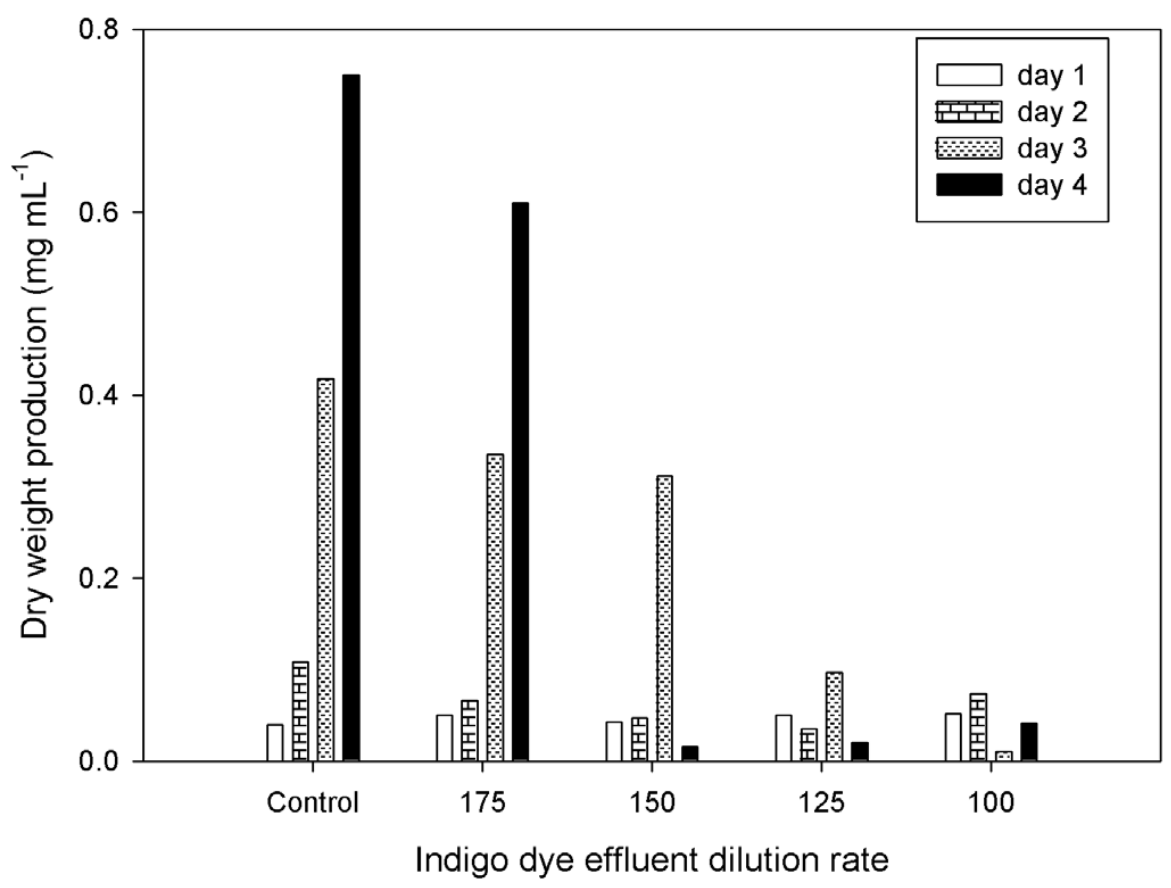

Fig. 3 - Dry weight production $\left(\mathrm{mg} \mathrm{L}^{-1}\right)$ by Scenedesmus quadricauda when grown at different indigo dye effluent concentrations.

Results related to the phenotypic plasticity of S. quadricauda can be seen in Figs. 4 and 5. The higher the concentration of dye effluent, the higher the numbers of single cells observed. However, more 4 celled organisms per coenobium were obtained at lower dye effluent concentrations. The changes in the number of single cells, 3 cells and 4 cells produced per coenobium were significantly different between the treatments $(p<0.05)$. The production of 2 cells per coenobium was only significantly different over time $(p<0.05)$, while no significant interaction between the exposure time and effluent concentration $(p>0.05)$ was observed.

Principal components analysis showed that lower dye concentrations (i.e. higher dilution rates) were positively $(p<0.05)$ associated with dry weight production, cell density and high (3 and 4) number of cells per coenobium (Fig. 6). Single cells and 2 cells per coenobium showed a negative association with low dye concentration. Exposure time was positively $(p<0.05)$ correlated with cell density, 4 cells per coenobium and dry weight production.

\section{DISCUSSION}

From the results of this study, it can be observed that indigo dye effluent is toxic to $S$. quadricauda, having negative effects on growth, biomass production and the number of cells per coenobium. This agrees with the findings of other studies (Mathur et al. 2012). The indigo dye effluent was rich in dissolved and suspended solids and heavy metals. These components including the dye itself can be implicated for the reduction in growth and biomass productivity of the microalga with increasing concentrations of the dye. Due to the fact that it is not always possible to analyze the ecotoxicological effects of individual compounds found in the dye effluent, the effect of the complex effluent mixture is what microalgae in aquatic ecosystems are exposed to. For example, the $\mathrm{Cd}$ like any of the other heavy metal reported in this study in the effluent has been reported to exhibit negative effects on the growth and biomass production of the freshwater microalga Chlorella vulgaris at environmentally relevant concentrations 

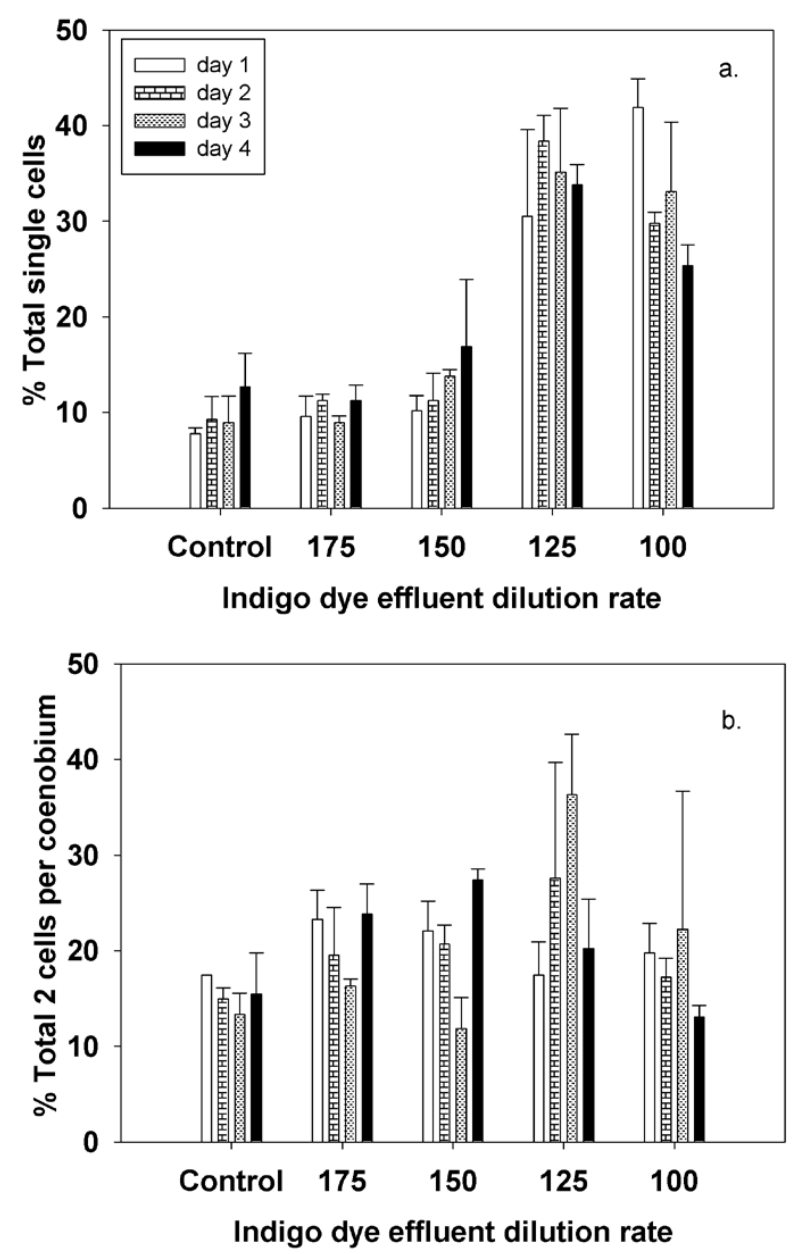

Fig. 4 - Percentage of total production of single cells (a) and 2 cells per coenobium (b) of Scenedesmus quadricauda exposed to different indigo dye effluent concentrations.

(Chia et al. 2013a, b). These components are capable of interacting in an additive, synergistic or even antagonistic way to affect the growth, biomass production and biochemical composition of microalgae (Chia et al. 2013a).

At very low concentrations the effect of the dye effluents was minimal, which means that with proper comprehensive pretreatment before discharge into aquatic ecosystems, their acute effect could be significantly reduced. Although not much is known about the effect of indigo dye effluent on microalgae, reports on higher plants show that reactive dyes can be carcinogenic and mutagenic (Puvaneswari et al. 2006). Our results agree with
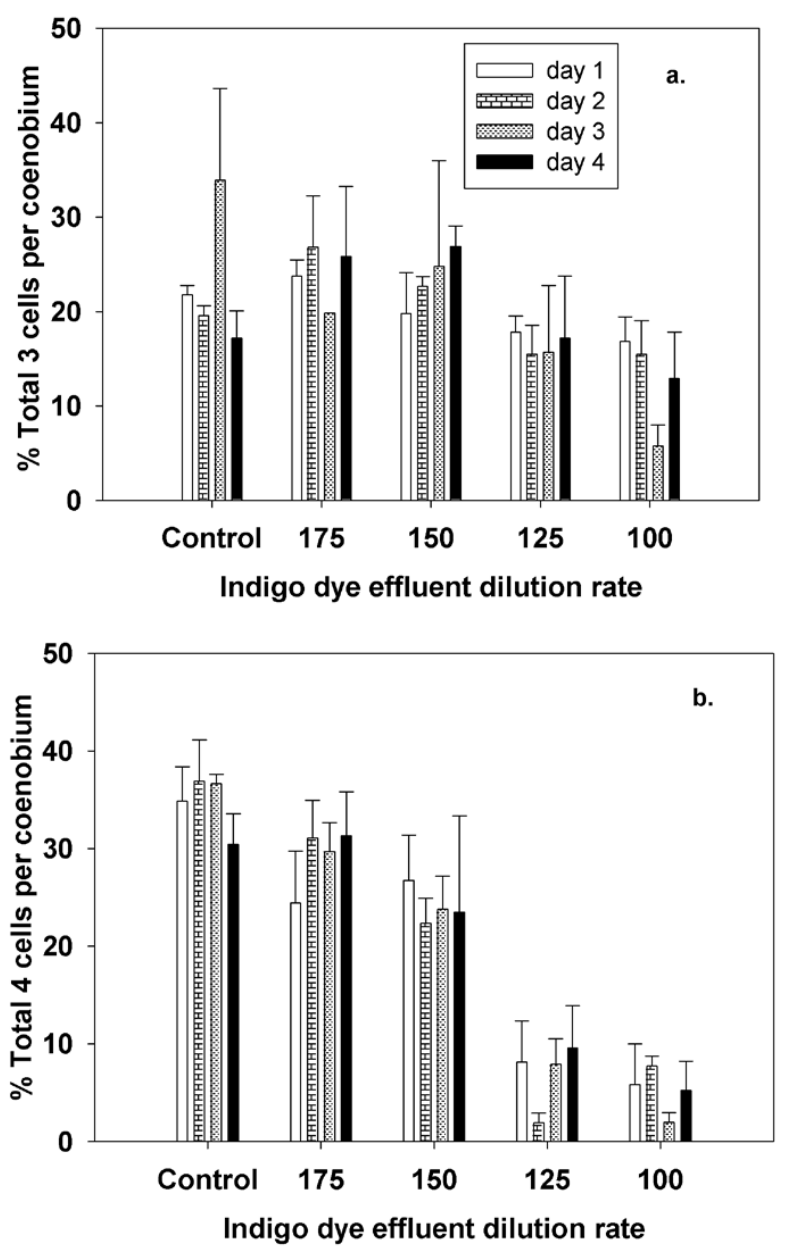

Fig. 5 - Percentage of total of 3 cells per coenobium (a) and 4 cells per coenobium (b) of Scenedesmus quadricauda as a function of different indigo dye effluent concentrations.

those of other authors that show that effluents from textile industries even after treatment can remain toxic, before their eventual release into the environment (Umbezeiro et al. 2004, Malachová et al. 2006, Alves de Lima et al. 2007, BergstenTorralba et al. 2009). Lim et al. (2010) observed that the growth of $C$. vulgaris decreased with increasing concentrations of textile wastewater. This agrees with the findings of our study where the growth and biomass accumulation of $S$. quadricauda decreased with increasing dye effluent concentration. However, in our study the toxicity of indigo dye effluent was much higher than that obtained by Lim et al. (2010). In addition, Rosa et al. (2007) were 


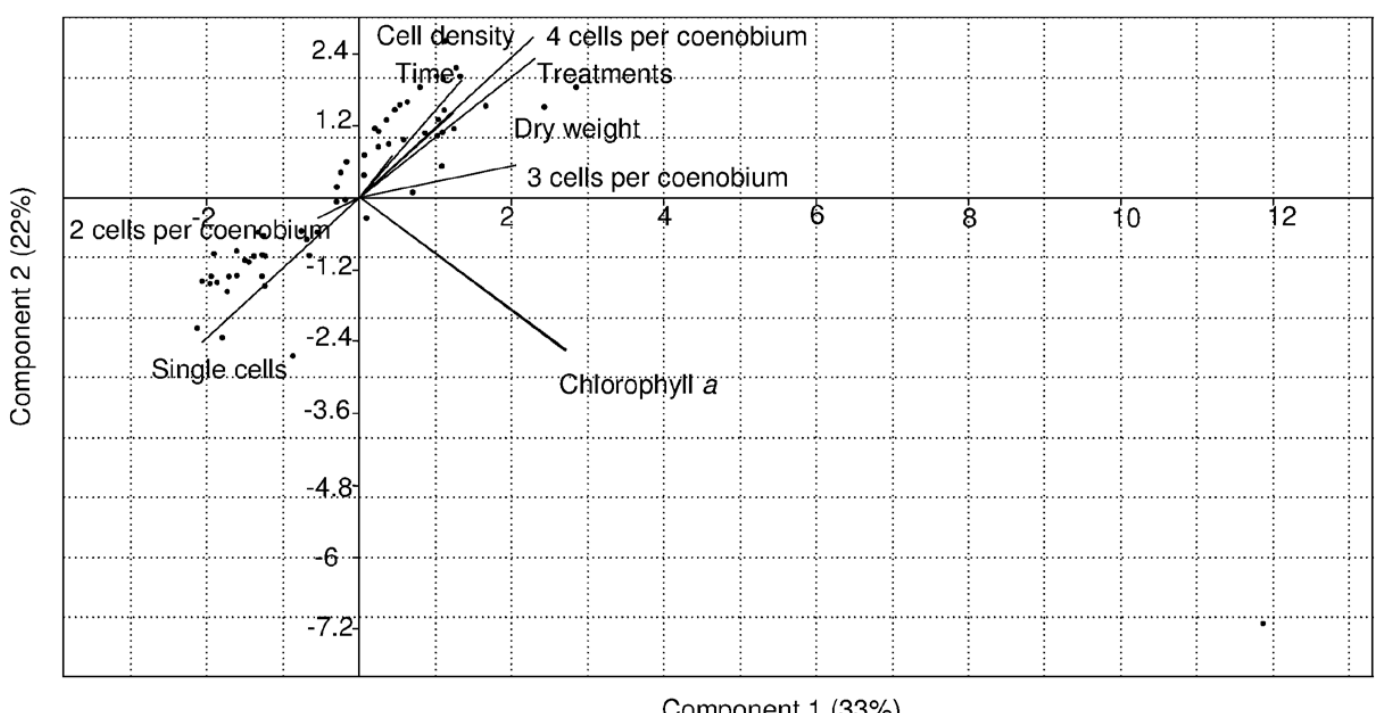

Component 1 (33\%)

Fig. 6 - Principal components analysis (PCA) biplot showing the correlation between different growth, biomass and morphological parameters of Scenedesmus quadricauda exposed to different indigo dye effluent concentrations.

able to show that fresh textile sludge inhibited the growth and biomass production of $S$. subspicatus. Indigo as a dye which forms the principal component of the textile effluent used in this study was reported by Cheriaa et al. (2009) to inhibit the growth and biomass production of the freshwater microalga Chlorella. Similar to our findings, these authors showed that low dye concentrations were capable of negatively impacting the physiology of the microalga. Furthermore, weight reduction as another biomarker, has been observed to be a common response of freshwater microalgae to the toxic effect of textile effluents due to reduced photosynthesis and cell division (Roy et al. 2010).

The use of biomass production and growth are the usual biomarkers for phytotoxicity evaluation. However, morphological variations also present effects of pollutants on microalgal physiology and can serve as important biomarkers. Morphological adaptations of microalgae have potential applications in monitoring and in ecotoxicology related investigations (Lombardi et al. 2007). Here we observed that the changes in number of cells per coenobium also known as phenotypic plasticity demonstrated significant correlations with the indigo dye effluent concentrations to which the microalga was exposed. Significant physiological effects can be deduced from this observation as a shift from high to low number of cells per coenobium with increasing indigo dye effluent concentration. This finding implies that the changes in coenobium structure observed for $S$. quadricauda can be used as an important biomarker for ecotoxicological investigations of indigo dye effluents, heavy metals and other pollutants.

Several mechanisms have been suggested to be responsible for the formation of coenobium in microalgae (Pickett-Heaps 1975). Nevertheless, the mechanisms involved in coenobium size reduction are unclear. Although, the plasticity findings in this study are similar to results obtained for $S$. acuminatus and $S$. incrassulatus exposed to toxic concentrations of ionic copper by Lombardi et al. (2007) and PeñaCastro et al. (2004), respectively, a few exceptions were observed in this study. They did not report 3 cells per coenobium in $S$. acuminatus whereas in S. quadricauda under the present experimental conditions, this morphological variation was 
observed. Furthermore, the highest number of cells per coenobium observed in this study was 4 cells, which is unlike what was obtained by Lombardi et al. (2007) with even 8 cells per coenobium occurring at low $\mathrm{Cu}^{++}$concentrations. It is possible to relate our findings to Lombardi et al. (2007) because of the evidence of heavy metal contamination of the effluent we tested. However, the differences between our study and theirs may be due to the fact that the microalgae investigated in both studies are of two different species, and also due to the nature of the stress to which they were exposed.

Conclusions can be made that these results show that indigo dye effluents exhibit acute toxicity effects on the microalga $S$. quadricauda at the concentrations tested in this study. Therefore, there is the risk of disrupting the primary aquatic food chain when untreated indigo dye effluents are discharged into aquatic systems. Recommendations are made that long term studies be carried out to show the chronic effect of the dye on the growth, biomass production, biochemical composition and genotoxicity for freshwater microalgae because this information is currently lacking. The systematic reduction in the number of cells per coenobium observed in this study further confirms that environmental stress can affect coenobium structure in Scenedesmus and that this feature offers a sensitive biomarker for toxicity testing.

\section{RESUMO}

$\mathrm{O}$ efeito do corante índigo de efluente na microalga Scenedesmus quadricauda de água doce foi investigado sob condições controladas de laboratório. A microalga foi exposta a diferentes concentrações do efluente obtido diluindo o efluente corante de 100 a 175 vezes em Bold Basal Medium (BBM). A taxa de crescimento da microalga diminuiu enquanto a concentração do efluente do corante índigo aumentou $(p<0,05)$. A EC50 foi encontrada como fator 166 de diluição do efluente. A clorofila a, a densidade celular e a produção biomassa seca como biomarcadores foram afetadas negativamente pela alta concentração de efluente do corante índigo, desde que seus níveis foram mais altos em baixas concentrações de efluentes $(p<0,05)$. Alterações no tamanho de cenóbios significativamente correlacionaram com a concentração de efluente. Obteve-se uma mudança de grandes para pequenos cenóbios, com o aumento da concentração de efluente de corante índigo. Podemos concluir que mesmo em baixas concentrações, efluentes de processos industriais têxteis que usam corante índigo são capazes de reduzir significativamente o crescimento e a produção de biomassa, além de alterar as características morfológicas da microalga da água doce $S$. quadricauda. A redução sistemática do número de células por cenóbio observada neste estudo confirma, ainda, que o estresse ambiental afeta a estrutura docenóbio do gênero Scenedesmus, o que significa que ele pode ser considerado um biomarcador importante para ensaios de toxicidade.

Palavras-chave: água doce, microalga, variação morfológica, poluição, resíduos têxteis.

\section{REFERENCES}

Alves de Lima ROA, BAZO AP, SALVAdori DMF, RECH CM, Oliveira DP AND UMBUZEIRO GA. 2007. Mutagenic and carcinogenic potential of a textile azo dye processing plant effluent that impacts a drinking water resource. Mutat Res 626(1-2): 53-60.

APHA - American Public Health Association. 1998. Standard methods for the examination of water and wastewater $\left(20^{\text {th }}\right.$ edn $)$. Washington DC: American Public Health Association, American Water Works Association/ Water Environmental Federation.

Bergsten-Torralba LR, NishikaWA MM, BAPTista DF, MagalHães DP AND DA SILVA M. 2009. Decolorization of different textile dyes by Penicillium simplicissimum and toxicity evaluation after fungal treatment. Braz J Microbiol 40: 808-817.

CheriaA J, Bettaieb F, Denden I And Bakhrouf A. 2009. Characterization of new algae isolated from textile wastewater plant. J Food Agric Environ 7: 700-704.

ChIA AM, LOMBARdi AT, MElaO MGG AND PARRISH CC. 2013a. Lipid composition of Chlorella vulgaris (Trebouxiophyceae) as a function of different cadmium and phosphate concentrations. Aquat Toxicol 128: 171-182.

ChIA AM, LOMBARdi AT, MElaO MGG AND PARRISH CC. 2013b. Effects of cadmium and nitrogen on lipid composition of Chlorella vulgaris (Trebouxiophyceae). Eur J Phycol 48(1): 1-11. 
JÄGER I. 1998. Research Feasibility Study, Hydrotox GmbH, Report to the European Commission.

KHANDELWAL S. 1996. Impact of dyeing industries, wastewater on vegetation of Luni catchment area: A case study through remote sensing technique. J Environ Poll 3(2): 77-78.

KNASMÜller S, ZÖHRER E, KAINZBAUER E, KIENZL H, COLBERT B, LAMPRECHT G AND SCHULTE-HERMANN R. 1993. Detection of mutagenic activity in textiles with Salmonella typhimurium. Mutat Res 299: 45-53.

Lim SL, Chu WL AND Phang SM. 2010. Use of Chlorella vulgaris for bioremediation of textile wastewater. Bioresource Technol 101: 7314-7322.

LOMBARDI AT, THAIS MDH, ARMANDO AHV AND ANTONIO LS. 2007. Toxicity of ionic Copper to the freshwater microalga Scenedesmus acuminatus (Chlorophyceae, Chlorococcales). Phycologia 46(1): 74-78.

LURLING M AND BEEKMAN W. 2002. Extractable substances (anionic surfactants) from membrane filters induce morphological changes in the green alga Scenedesmus obliquus (Chlorophyceae). Environ Toxicol Chem 21: 1213-1218.

LURLING M AND VAN DONK E. 1999. Grazer-induced colony formation in Scenedesmus acutus (Chlorophyceae): ecomorphological expression at different temperature. J Phycol 35: 1120-1126.

Malachová K, Pavlícková Z, Novótny C, Svobodová K, LEDNICKÁ D AND MusílKOVÁ E. 2006. Reduction in the mutagenicity of synthetic dyes by successive treatment with activated sludge and the ligninolytic fungus, Irpex lacteus. Environ Mol Mutagen 47: 533-540.

MATHUR NAND BHATNAGAR P. 2007. Mutagenicity assessment of textile dyes from Sanganer (Rajasthan). J Environ Biol 28(1): 123-126.

Mathur N, Bhatnagar P AND BaKre P. 2005a. Assessing mutagenicity of textile dyes from Pali (Rajasthan) using Ames bioassay. Appl Ecol Env Res 4(1): 111-118.

Mathur N, Bhatnagar P, Dhewa T, Bose T and Chug S 2005b.Genotoxic effects of Black RL and Green 6B Dyes used in Textile Industries. Toxicol Int 12 (1): 5-8.

Mathur N, Bhatnagar P AND Sharma P. 2012. Review of the mutagenicity of textile dye products. Universal $\mathrm{J}$ Environ Res Technol 2(2): 1-18.

NÉMETH J. 1998. A biológiaivízmin ő sítésmódszerei. Környezetgaz-dálkodásiIntézet. TOI Környezetvédelmi Tájékoztató Szolgálat, Budapest.

Novotny C, Dias N, Kapanen A, Malachova K, VANDROVCOVA M, ITAVAARA M AND LIMA N. 2006. Comparative use of bacterial, algal and protozoan tests to study toxicity of azo- and anthraquinone dyes. Chemosphere 63: 1436-1442.

PeÑa-Castro JM, MartineZ-Jeronimo F, Esparza-Garcia F AND CANIZAREs-VillanueVA RO. 2004. Phenotypic plasticity in Scenedesmus incrassulatus (Chlorophyceae) in response to heavy metals stress. Chemosphere 57: 1629-1636.

PicketT-HEAPS JD. 1975. Green algae. Sinauer Associates, Sunder-land, MS.
PUVANESWARI N, MUTHUKRISHNAN J AND GUNASEKARAN P. 2006. Toxicity Assessment and microbial degradation of Azo dye. Indian J Exp Biol 44: 618-626.

RAJ GB, PATNAIK MC AND SUBBAIAH VV. 1997. Heavy metal pollution in soil and fodder (paragrass) irrigated with sewage and effluent water all along Musi River. Proc Acad Environ Biol 6(2): 177-182.

RANNUG U, BAMSTEDT H AND NILSSON U. 1992. The presence of genotoxic and bioactive components in indigo dyed fabrics-a possible health risk? Mutat Res 282(3): 219-225.

Robinson T, MCMullan G, Marchant R and NigAM P. 2001. Remediation of dyes in textile effluent: a critical review on current treatment technologies with a proposed alternative. Bioresource Technol 77: 247-255.

RocHA AA. 1992. Algae as biological indicators of water pollution. In: CORDEIRO-MARINO M, PAIVAAZEVEDO MA, SANT'ANNA CL, TOMITA NY and PLASTINO EM (Eds), Algae and the environment: a general approach. Sociedade Brasileira de Ficologia, São Paulo, p. 34-52.

Rosa EVC, GIURAdelli TM, CORRÊA AXR, RÖRIG LR, SCHWINGEL PR, RESGALla-JR C AND RADETSKI CM. 2007. Ecotoxicological evaluation of the short term effects of fresh and stabilized textile sludges before application in forest soil restoration. Environ Pollut 146: 463-469.

ROY R, FAKHRUDDIN ANM, KHATUN R, ISLAM MS AHSAN MA AND NEGER AJMT. 2010. Characterization of Textile Industrial Effluents and its Effects on Aquatic Macrophytes and Algae. Bangladesh J Sci Indust Res 45(1): 79-84.

SHOAF TW AND LIUM BW. 1976. Improved extraction of chlorophyll $\mathrm{a}$ and $\mathrm{b}$ from algae using dimethylsulphoxide. Limnol Oceanogr 21: 926-1054.

SRIVASTAVA SK, KumAR R AND SRIVASTAVA AK. 1994. Effect of textile industry effluents on the biology of river Tons at Mau (U.P.) I Physicochemical characteristics. Poll Res 13(4): 369-373.

UMBUZEIro GA, RoUBicEK RA, Oliveira DP, MURAKAMI D, COIMBRÃO CA AND STRAUS EL. 2004. Mutagenic activity of sludge samples generated in dyeing processing textile plants. Rev Bras Toxicol 17: 29-36.

VAN Den Hoek C, Mann D AND Jahns HM. 1995. Algae, an introduction to phycology. Cambridge University Press, New York.

WILLIAMS DH AND FLEMING I. 2005. Spectroscopic methods in organic chemistry ( $5^{\text {th }}$ edn). Delhi: Tata McGraw-Hill.

ZOLLINGER H. 1987. Colour chemistry-synthesis, properties and applications of organic dyes and pigments. $\mathrm{VCH}$, New York, p. 92-100. 